\title{
Changes in Cell Wall Components of Pinus sylvestris L. Wood after 300 Years in Contact with Salt (NaCl)
}

\author{
Alberto García-Iruela, ${ }^{\text {a,* }}$ Luis García Esteban, ${ }^{\text {a }}$ Paloma de Palacios, ${ }^{\text {a }}$ \\ Francisco García Fernández, ${ }^{\mathrm{a}}$ Raquel Martín-Sampedro, ${ }^{\mathrm{b}}$ and María E. Eugenio ${ }^{\mathrm{b}}$ \\ Changes were evaluated in cell wall components, hygroscopicity, and \\ thermodynamic properties of Pinus sylvestris L. wood that had been in \\ contact with salt $(\mathrm{NaCl})$ for 300 years in a former saltworks storehouse in \\ Gerri de la Sal (Lérida, Spain), comparing it with recently felled wood \\ (new wood) of the same species. The wood in contact with salt (salt- \\ covered wood) had higher equilibrium moisture content values except in \\ the first interval of the adsorption isotherm, probably because of \\ mechanical blocking of polar sites by salt crystals. The high fibre \\ saturation point values of this wood are caused by the salt dissolved in \\ water above water activity of about 0.75 . More energy is invested in the \\ desorption process, and the values are higher in the salt-covered wood.
}

Keywords: Dynamic vapour sorption; Hygroscopicity; Isotherms; Thermodynamic properties; Sorption; Impregnated wood

Contact information: a: Departamento de Sistemas y Recursos Naturales, Cátedra de Tecnología de la Madera, Escuela Técnica Superior de Ingeniería de Montes, Forestal y del Medio Natural, Universidad Politécnica de Madrid, Ciudad Universitaria, 28040, Madrid (Spain); b: Instituto Nacional de Investigación y Tecnología Agraria y Alimentaria, INIA, Carretera de la Coruña, km 7.5, 28040, Madrid (Spain); *Corresponding author: agiruela17@gmail.com

\section{INTRODUCTION}

Over time and in certain ambient conditions, structural wood can be subjected to the action of biotic agents (bacteria, algae, fungi, lichens, insects, molluscs and crustaceans) or abiotic agents - whether chemical (acids, alkalis, oxygen, ozone, salts, aerosols, pollution gases) or physico-chemical (solar radiation, nuclear radiation, thermal radiation or fire) - and physico-mechanical factors (low temperatures, physical action of water, cyclic moisture, sustained loads, periodic loads, impact loads, rubbing) (Wazny 1993). These agents can degrade the lignocellulosic complex in the cell wall, mainly the polysaccharides (Fengel 1991), which in turn modify the hygroscopic response and thermodynamics of wood. Studying the hygroscopic behaviour of naturally or artificially aged wood gives a better understanding of the water sorption mechanisms of wood. If the wood has been exposed to unusual conditions or situations that are not easily reproduced in controlled experiments, the results provide very valuable information about sorption by wood.

The combined action of degradation in archaeological wood due to simultaneous action of abiotic and biotic factors is very difficult to assess separately, because both types of factors can degrade the same cell wall components. For example, tunnelling bacteria and some white-rot species preferably attack lignin, eroding all cell walls and degrading the middle lamella (Blanchette 2000). Abiotically, prolonged acidic hydrolysis in the absence of microorganisms can modify not only carbohydrates, but also residual 
lignin (Blanchette et al. 1991).

In this instance, the action of a chemical abiotic agent (sodium chloride) and the possible presence of a biotic attack when the structure was first erected allow prolonged wood-salt interaction to be studied.

Using the sorption isotherms is a good method to determine the hygroscopic behaviour of wood. Popescu and Hill (2013) studied the effect of ageing in historic Tilia cordata Mill. wood exposed for 110, 160, 170, and 240 years and found that there was no simple correlation between exposure time and the sorption behaviour of wood. The oldest sample showed similar behaviour to that of new wood of the same species used as a control. Other studies reported different behaviour in recently felled wood and samples of the same species in varying conditions and exposure times. Esteban et al. (2006) and Esteban et al. (2008a) showed that the equilibrium moisture content (EMC) of 18th century Pinus sylvestris L. wood subjected to non-aggressive exposure in the beamwork of Aranjuez Palace (Spain) was higher than the EMC of recently felled wood. Esteban et al. (2009) studied another sample of P. sylvestris wood that had been buried and was more than 1000 years old, and Esteban et al. (2010) studied buried Quercus spp. wood aged almost 6000 years in the Ría Villaviciosa area, a marine environment. In the latter two studies, the adsorption-desorption isotherms of the old wood were above those of recently felled wood of the same species, mainly due to the increase in active - $\mathrm{OH}$ sites. Simon et al. (2017a) demonstrated polysaccharide degradation due to high temperatures and the high percentage of extractives in Pinus canariensis C. Sm. ex D.C. wood buried in pyroclastic ash after an eruption about 3,000 years ago, resulting in lower EMC in the wood buried in ash than in recently felled wood of the same species.

Few studies have been conducted on the behaviour of wood treated with salt $(\mathrm{NaCl})$. Loughborough in (Kollmann 1959) reported that sodium chloride causes higher EMC and higher fibre saturation points; Lesar et al. (2009) characterised Picea abies Karst. wood artificially impregnated with salt; and Petr and Dejmal (2014) studied the effects of various salt concentrations on Populus alba L. No studies were found on wood naturally impregnated with salt.

Using wood that has been in contact with salt for 300 years enables the study of a material subjected to unique conditions rather than the artificial conditions of typical laboratory procedures or industrial impregnation. It provides a unique opportunity to compare such wood with recent samples of the same species to determine possible chemical changes in the cell wall, variations in the cellulose crystallinity indices, changes in the hygroscopic response, and any differences in the thermodynamic parameters associated with the sorption process.

Because the wood had spent a long time in contact with salt, under cover, and at reasonably constant relative humidity $(\mathrm{RH})$ and temperature, the samples have high scientific value.

The possible biotic and abiotic ageing of the wood, combined with the presence of salt and its osmotic properties, must have influenced the cell wall components, and therefore the wood can be presumed to have different hygroscopic behaviour as a result.

This study analyses the possible changes in the cell wall components and relates them to the hygroscopic and thermodynamic behaviour of recently felled Pinus sylvestris wood and wood of the same species that had been in contact with salt in the salt storehouse in Gerri de la Sal (Lérida, Spain) for 300 years. 


\section{EXPERIMENTAL}

\section{Materials and Methods}

\section{Salt-covered wood}

Samples were obtained from three beams forming part of the wooden structure of the Real Alfolí building, in Gerri de la Sal, on the banks of the Noguera Pallaresa river, province of Lérida (Spain). This building is the largest non-religious construction in the Pallars-Sobirá region, and for 300 years it was used to store salt from the saltworks in Gerri.

Salt extraction began to decline in the 1960s, and the 1982 flood in Noguera Pallaresa brought an end to the saltworks and salt storage. However, the entire wood structure still has salt adhered to it. The salt-covered wood has been preserved as testimony to the history of the building, which was designated as a National Heritage Asset (Fig. 1) in 1995 and now houses the saltworks museum. The building has a square ground plan with sides of around 25 metres, rubblework walls and a wooden structure. Documents held by the town hall show that the wood used in its construction was pine from the local area, and except for the recent addition of a staircase, the wood is all original. Two beams removed to install a staircase were calculated to be more than 65 years old from the growth ring count. Following habitual practice among carpenters of the time, only pieces from the centre of the tree were used for the wooden structures, giving an idea of the age of the timber used in the construction.
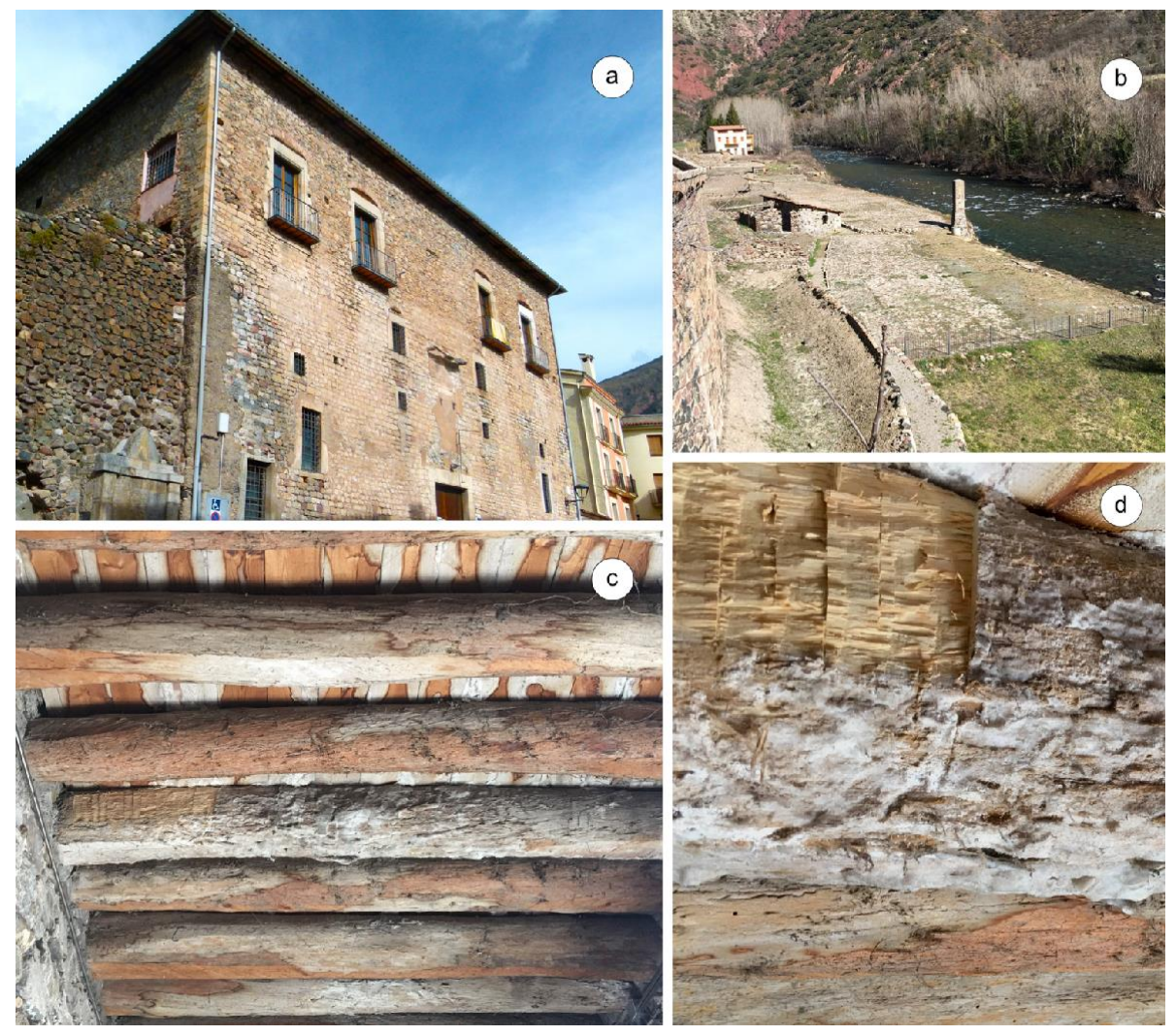

Fig. 1. a) Real Alfolí salt storehouse - Gerri de la Sal, Lleida (Spain); b) remains of the former saltworks on the banks of the Noguera Pallaresa river; $c$ ) wooden framework beam in contact with salt for 300 years; and d) sample extraction site, surrounded by accumulated salt 
The saltworks once produced as much as 1,000 tonnes annually, and the structure of the building was in contact with salt virtually all year. Humidity and temperature were never controlled in the storehouse. Ventilation was natural, through the windows and openings made in the front of the building, for further drying after the salt had been extracted in the sun in evaporation ponds.

Sawdust was obtained from mature heartwood and sieved to $0.2 \mathrm{~mm}$, the particle size necessary to plot the isotherms using DVS, determine the chemical composition and crystallinity index, and perform FTIR.

\section{Wood Identification}

To check for the presence of degradation and identify the wood anatomically, thin microscope slides $(15-20 \mu \mathrm{m})$ were prepared from the transverse, tangential, and radial sections of a $15 \times 15 \times 15 \mathrm{~mm}$ oriented sample taken from each beam at a depth of $15 \mathrm{~mm}$ after incrusted salt had been removed from the surface of the wood. A LEICA SM2400 microtome was used (Leica Biosystems, Barcelona, Spain).

To obtain the thin section slides, samples were softened by boiling in a mixture of $50 \%$ water and glycerine for one hour. Slides were stained with a mixture of $0.5 \mathrm{~g}$ safranine powder, $100 \mathrm{~mL}$ distilled water, and $100 \mathrm{~mL} 96 \%$ alcohol. Excess reagent was removed with $96 \%$ alcohol. Samples were dehydrated for mounting with $96 \%$ alcohol and pure alcohol, respectively. Excess pure alcohol was removed and samples were submerged in xylene until mounting with Eukitt.

Observations were made using light microscopy LEICA DM2500 (Leica Biosystems, Barcelona, Spain). The wood was identified using the keys included in Esteban and Guindeo (1988) and Esteban et al. (2002) and described following the IAWA Committee (2004).

The wood in contact with salt has distinct growth rings with abrupt transition, axial and transverse resin canals with thin-walled epithelial cells, longitudinal and radial tracheids without helical thickenings, heterogeneous rays with mostly dentate ray tracheids and window-like cross-field pits. The features of the pines in this area concur with those of Pinus sylvestris L. (Fig. 2). 


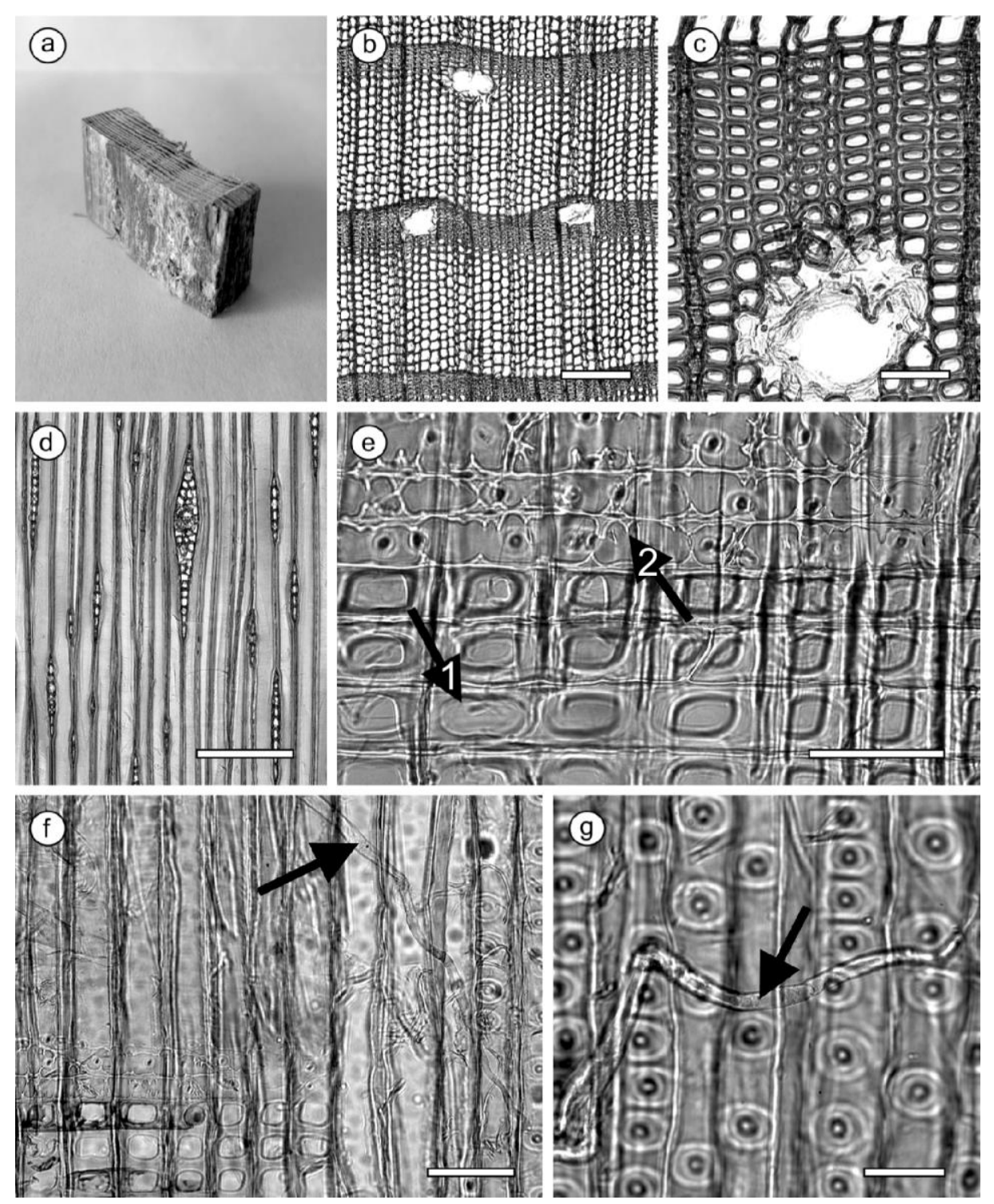

Fig. 2. Salted wood, microscope identification, and attacks. a) Sample of salted wood extracted from a beam. Transverse section: b) Distinct growth rings with abrupt transition; c) Axial resin canal with thin-walled epithelial cells. Tangential section: d) Multiseriate ray with radial resin canal. Radial section: e) Arrow 1.- Window-like cross-field pit, Arrow 2.- Dentate thickening in ray tracheids; f) and g) Arrows indicate fungus hyphae. Scale bars for b and d: $250 \mu \mathrm{m}$; $c$ and f: 100 $\mu \mathrm{m}$; e and g: $50 \mu \mathrm{m}$.

\section{Reference Material (new wood)}

The reference material (new wood) used to compare the isotherms of the wood in contact with salt and new wood was recently felled wood of the same species (Pinus sylvestris L.) from the forest in the same location and therefore from the same region of provenance.

Taking the reference material from the same region of provenance avoided anatomical variability due to site adaptability exhibited by the species in its different regions of provenance due to soil, climate, altitude, etc. (Martín et al. 2010). To avoid variation among trees, three trees representative of the area were felled. The trees were 
more than 90 years old and neither dominant nor dominated. Individuals influenced by the stand edge effect or with signs of compression wood were avoided. A disc was cut from each tree $1.30 \mathrm{~m}$ from the ground. Mature wood samples were obtained from the discs for comparison with mature wood from the beams in contact with salt.

\section{Sorption Isotherms}

The isotherms were plotted by dynamic vapour sorption (DVS) using the Q5000SA Sorption Analyzer (TA Instruments, New Castle, DE, USA), weight range 0.1 $\mathrm{g}$, weighing accuracy $0.1 \%$, temperature range 5 to $85{ }^{\circ} \mathrm{C}$, isothermic stability $0.1{ }^{\circ} \mathrm{C}$, relative humidity range 0 to $98 \%$, relative humidity precision $\pm 1 \%$. Particle size was 0.2 $\mathrm{mm}$. The $15{ }^{\circ} \mathrm{C}$ and $35{ }^{\circ} \mathrm{C}$ isotherms were plotted, starting from saturated samples to avoid hysteresis peaks that could have led to erroneous interpretation of results (Fredriksson and Thybring 2018). The reference material sample did not require saturation because the desorption isotherm was plotted immediately after felling. The samples of salt-covered wood were submerged in a container with deionised water until they fell to the bottom, at which point they were considered to be saturated. Samples were dried immediately and excess water was removed before they were placed in the DVS. The isotherms were plotted using nine equilibrium points from 10 to $90 \%$, inclusive, at $10 \%$ intervals. The sample was considered to have reached equilibrium when the change in mass $(\mathrm{d} m / \mathrm{d} t)$ was less than $0.001 \% \mathrm{~min}^{-1}$ for $10 \mathrm{~min}$. The change in mass was recorded every minute (Simon et al. 2017b). Moisture content was determined using Eq. 1,

$$
\operatorname{EMC}(\%)=\frac{W_{w}-W_{0}}{W_{0}} \cdot 100
$$

where $W_{w}$ is wet weight $(\mathrm{g})$ and $W_{0}$ is anhydrous weight $(\mathrm{g})$

The sorption isotherms were fitted using the GAB (Guggenheim-Anderson-de Boer) model, which is widely used with wood (Arevalo-Pinedo et al. 2004; Jannot et al. 2006) (Eq. 2),

$$
X=\frac{K \cdot C_{g} \cdot a_{w}}{\left(1-K \cdot a_{w}\right)\left(1-K \cdot a_{w}+C_{g} \cdot K \cdot a_{w}\right)} \cdot X_{m}
$$

where $X$ is equilibrium moisture content EMC (\%), $X_{m}$ is monolayer saturation moisture content (\%), $C_{g}$ is Guggenheim constant (dimensionless), $K$ is a constant (dimensionless), and $a_{w}$ is water activity (dimensionless). The isotherms were considered valid at $\mathrm{R}>$ 0.990 and RMSE < 4\% (Viollaz and Rovedo 1999; Esteban et al. 2008a, 2009).

\section{Chemical Composition}

Both the salt-covered wood and the new wood were analysed chemically. The ash content was determined at $525{ }^{\circ} \mathrm{C}$ using TAPPI 211 om-02 standard (2002). National Renewable Energy Laboratory Procedure NREL/TP-510-42619 (Sluiter et al. 2005) was used to determine ethanol extractives. Two-step hydrolysis was used to analyse lignin and sugar content, applying NREL Laboratory Analytical Procedure NREL/TP-51042618 (Sluiter et al. 2012). High performance liquid chromatography was applied to determine sugar content, using an Agilent Technologies 1260 HPLC (Santa Clara, CA, USA) with an RI-detector and an Agilent Hi-Plex Pb column. Using water as the mobile phase, separation was performed with a flow of $0.6 \mathrm{~mL} \mathrm{~min}^{-1}$ at $70{ }^{\circ} \mathrm{C}$. 
Cellulose and hemicellulose content (hexoses and pentoses) was calculated from the sugar content (Easty and Malcolm 1982; Vaaler et al. 2005; Jones et al. 2006) (Eqs. $3,4,5$, and 6),

$$
\begin{aligned}
& \left.\operatorname{Cel}(\%)=\text { Glu-( } \frac{1}{3} \text { Man }\right) \\
& \text { Hexosan }(\%)=(\text { Gal }+ \text { Glu }+ \text { Man })-\text { Cel } \\
& \text { Pentosan }(\%)=\text { Ara }+ \text { Xyl } \\
& \text { Hem }(\%)=\text { Hexosan }+ \text { Pentosan }
\end{aligned}
$$

where the contents (in \%) are cellulose ( $\mathrm{Cel}$ ), glucan $(\mathrm{Glu})$, mannan (Man), galactan $(\mathrm{Gal})$, arabinan $(\mathrm{Ara})$, xylan $(\mathrm{Xyl})$, and hemicellulose $(\mathrm{Hem})$. A 95\% confidence interval was determined for each compound of the samples.

\section{Crystallinity}

The crystalline fraction of the cellulose was determined using X-ray diffraction. Although crystallinity index determination by X-ray must be assumed not to take the preferred orientation of crystalline cellulose into account (Thygesen et al. 2005), and it is difficult to define the boundary between the wood ordered and amorphous areas with this method (Bonarski and Olek 2011), this technique was used because it is the most common method for wood crystallinity determination. The X-ray diffraction method chosen was deconvolution, because it has values closer to the real value of cellulose crystallinity than the method developed by Segal et al. (1959). Even though the latter method is the most commonly used, many studies advise against it (Thygesen et al. 2005; Park et al. 2010; French and Santiago-Cintrón 2013).

The XRD peak deconvolution method requires the software used to separate amorphous and crystalline contributions to the diffraction spectrum through a curvefitting process. For the fitting, some assumptions must be made, such as the shape and number of peaks (Park et al. 2009). Gaussian functions (Teeäär et al. 1987; Hult et al. 2003), commonly used for deconvolution of XRD spectra, have on many occasions separated five crystalline peaks (110, 1-10, 102, 200, and 040) (Hult et al. 2003; Garvey et al. 2005), but in other studies four peaks have been assumed (110, 1-10, 200 and 040) (He et al. 2008), (110, 1-10, 102, 200) (Guo et al. 2016) and even three (110, 1-10, 200) (Rambo and Ferreira 2015; Guo et al. 2018). In this study, five were used. The contributing peaks are determined by the Miller indices included in French et al. (2014). The iterations were repeated until a value of $\mathrm{R}^{2}>0.997$ was obtained (Park et al. 2010).

D200, the radial width of the (200) reflection in cellulose I $\beta$, has been widely used as a guide to the diameter of the crystalline part of microfibrils (Leppänen et al. 2009; Guo et al. 2016). Crystallite size (D200) was obtained by applying the formula of Scherrer, using the Bragg peak width as in numerous previous studies (Elesini et al. 2002; Andersson et al. 2003, 2004; García Fernández 2004; Jahan and Mun 2005; Esteban et al. 2006, 2008b, 2009, 2010; Lionetto et al. 2012; Fernández et al. 2014).

The crystalline fraction of the cellulose was determined in a Philips X'Pert (PANalytical Products, Royston, UK) (45 kV, $40 \mathrm{~mA}, 1800 \mathrm{~W})$. The deconvolution method was applied to determine the crystallinity index ( $\mathrm{CrI} \%)$ of the wood samples (Eq. 7) (Park et al. 2010; Guo et al. 2016, 2018), 


$$
\operatorname{CrI} \%=\frac{A_{1-10}+A_{110}+A_{102}+A_{211}+A_{200}}{A_{1-10}+A_{110}+A_{102}+A_{211}+A_{200}+A_{a m}} \times 100
$$

where $A_{h k l}$ are the areas of the peaks indicated by the Miller indices (French 2014) and $A_{\text {am }}$ is the amorphous contribution given by the broad peak.

Python programming language, version 3.6.3, was used to fit the measured data, assuming Gaussian functions for all peaks.

Scherrer's formula (Eq. 8) was used to calculate the average dimension $\left(D_{200}\right)$ of the cellulose crystallite from the Bragg peaks width,

$$
D_{200}=\frac{k \cdot \lambda}{F W H M \cdot \cos \theta}
$$

where $K$ is the correction factor ( $\mathrm{K}=0.9$ (dimensionless)), $\lambda$ is the emitting wavelength $(\lambda=1.54056(\AA))$, and FWHM is the full width at half maximum (in radians) of a Gaussian peak. A 95\% confidence interval was established for each sample for comparison of $\mathrm{CrI} \%$ and $L_{h k l}$ data.

The equation developed by Rowell (1980) (Eq. 9) was applied to calculate the number of theoretical -OH groups (mmol gr-1 of dry wood) (Hill and Jones 1996, 1999; Chang and Chang 2002; Hill 2006; Hill et al. 2009; Rautkari et al. 2013),

$$
\frac{3 A}{162}+\frac{3 B}{162}+\frac{2 C}{132}+\frac{D}{180}
$$

where the contents (in \%) are cellulose $(A)$, hexosan hemicellulose $(B)$, pentosan hemicellulose $(C)$, and lignin $(D)$.

To calculate the accessible $-\mathrm{OH}$ content, the theoretical content of the hydroxyl groups was corrected with the $\mathrm{CrI}(\%)$, considering that these groups are inaccessible in the crystalline portion of the cellulose (Hill and Jones 1999; Hill 2006; Hill et al. 2009, 2010; Rautkari et al. 2013).

\section{Functional Groups. Infrared spectroscopy (FTIR)}

Functional groups were identified by Infrared spectroscopy (FTIR) using ATR. A disc was prepared by extracting a $3 \mathrm{mg}$ sample of dry sawdust from each wood. Data were available after 64 scans had been completed using a Spectra-Tech Performer spectrophotometer (Thermo Fisher Scientific, Waltham, MA, USA) (4 $\mathrm{cm}^{-1}$ precision). Ten measures were made on each sample.

\section{Thermodynamic Properties}

Despite the limitations of obtaining the thermodynamic properties through current sorption models (Simpson 1980; Zelinka et al. 2018), these models were included in this study to determine the possible influence of the salt on the thermodynamic behaviour of the wood.

To calculate total isosteric heat of sorption (IHS), the following equation was applied (Avramidis 1997) (Eq. 10),

$$
Q_{s}=q_{s}+\Delta H_{v a p}
$$

where $Q_{s}$ is the total IHS $\left(\mathrm{J} \mathrm{mol}^{-1}\right), \Delta H_{\text {vap }}$ is the latent vaporisation heat (constant) ( $\mathrm{J} \mathrm{mol}^{-}$ 
$\left.{ }^{1}\right)$, and $q_{s}$ is the net IHS $\left(\mathrm{J} \mathrm{mol}^{-1}\right)$.

Net IHS was calculated by applying the integration method of the ClausiusClapeyron equation (Peralta et al. 1997) (Eq. 11),

$$
q_{s}=-R \cdot \frac{d\left[\ln \left(a_{w}\right)\right]}{d\left(\frac{1}{T}\right)}
$$

where $q_{s}$ is the net IHS $\left(\mathrm{J} \mathrm{mol}^{-1}\right), a_{w}$ is the water activity (dimensionless), $T$ is the absolute temperature $(\mathrm{K})$, and $R$ is the universal gas constant $\left(\mathrm{J}(\mathrm{mol} \mathrm{K})^{-1}\right)$.

Total heat of wetting, defined as the heat in the sorption process from fibre saturation point $(F S P)$ to oven drying (Siau 1995), was calculated by applying the integration of the net isosteric heat curve (Avramidis 1997) (Eq. 12),

$$
W_{0}=\int_{0}^{m_{f}} q_{s} \cdot d m
$$

where $W_{o}$ is the total heat of wetting $\left(\mathrm{J} \mathrm{mol}^{-1}\right.$ dry wood), $q_{s}$ is the net IHS $\left(\mathrm{J} \mathrm{mol}^{-1}\right)$, and $m_{f}$ is the FSP moisture content (\%).

\section{Statistical Analysis}

Data were statistically treated and analysed using the Statistics Toolbox ${ }^{\circledR}$ utility ver. 6.1, from MATLAB ${ }^{\circledR}$ ver. 7.5.0. Release 2007b.

For the sorption isotherms, a computer programme was developed to obtain the fit of the sorption curves and the confidence intervals of the parameters after transforming the GAB curve into a second degree parabola and fitting it using least squares.

To compare the results obtained in the chemical composition and the crystallisation and -OH group concentration data, an analysis of variance (ANOVA) with a confidence level of $95 \%$ was conducted, followed by LSD analysis. Ten repetitions were performed in each case and the normality, independence, and homoscedasticity of the data were studied before the ANOVA using the skewness, kurtosis, and Levene Test data.

\section{RESULTS AND DISCUSSION}

Slight degradation was observed in ray cells in rings at the perimeter of the beam, probably due to attack by a rot fungus whose development may have been prevented by the salt filling the storehouse. The osmotic power of salt is capable not only of dehydrating numerous organisms, but can also cause a medium in wood with insufficient water that may have prevented the development of fungi and bacteria after the storehouse was filled with salt. Both fungi and bacteria need high humidity to proliferate (Hill 2006).

All the isotherms fitted to a type II sigmoid typical of cellulosic materials (Avramidis 1997; Zahian et al. 2011; Engelund et al. 2013). The GAB model fit was considered valid because in all the isotherms $\mathrm{R}>0.990$ and RMSE $<4 \%$.

The isotherms of the salt-covered wood were expected to be above those of the new wood because of the hygroscopic nature of salt (Fig. $3 \mathrm{a}, \mathrm{b}$ ). The results obtained agree with those of other studies on artificial impregnation with $\mathrm{NaCl}$, e.g., in Picea abies 
(Lesar et al. 2009) and Populus alba (Petr and Dejmal 2014). In all the isotherms plotted there was a significant increase in EMC above water activity of about 0.7 . This behaviour is due to $\mathrm{NaCl}$ crystallising below 0.75 water activity, when it absorbs little water, whereas above this value, corresponding to the saturation point of the salt, the $\mathrm{NaCl}$ is bonded to the water and modifies the EMC (Kollmann 1959).

However, the EMC values in adsorption in the salt-covered wood to $30 \% \mathrm{RH}$ were lower than in the new wood for the two temperatures (Table 1).

Table 1. Equilibrium Moisture Content (\%) in Adsorption (EMCa) and Desorption $\left(E_{\mathrm{d}}\right)$ of New Wood and Salt-Covered Wood (NaCl wood) for 15 and $35^{\circ} \mathrm{C}$ Isotherms

\begin{tabular}{|c|c|c|c|c|c|c|c|c|}
\hline \multirow[b]{3}{*}{$a_{w}$} & \multicolumn{4}{|c|}{ New Wood } & \multicolumn{4}{|c|}{$\mathrm{NaCl}$ Wood } \\
\hline & \multicolumn{2}{|c|}{$15^{\circ} \mathrm{C}$} & \multicolumn{2}{|l|}{$35^{\circ} \mathrm{C}$} & \multicolumn{2}{|c|}{$15^{\circ} \mathrm{C}$} & \multicolumn{2}{|l|}{$35^{\circ} \mathrm{C}$} \\
\hline & $\mathrm{EMC}_{\mathrm{a}}$ & $\mathrm{EMC}_{\mathrm{d}}$ & $\mathrm{EMC}_{\mathrm{a}}$ & $\mathrm{EMC}_{\mathrm{d}}$ & $\mathrm{EMC}_{\mathrm{a}}$ & $\mathrm{EMC}_{\mathrm{d}}$ & $\mathrm{EMC}_{\mathrm{a}}$ & $\mathrm{EMC}_{\mathrm{d}}$ \\
\hline 0.1 & 2.73 & 3.97 & 2.44 & 3.34 & $2.03^{*}$ & 4.83 & $1.86^{*}$ & 3.56 \\
\hline 0.2 & 4.03 & 6.47 & 4.08 & 5.33 & $3.83^{*}$ & 7.06 & $3.46^{*}$ & 5.58 \\
\hline 0.3 & 5.53 & 8.5 & 5.14 & 7.09 & $5.35^{*}$ & 9.15 & $4.92^{*}$ & 7.33 \\
\hline 0.4 & 6.79 & 9.95 & 6.33 & 8.86 & 7.00 & 11.53 & 6.36 & 9.71 \\
\hline 0.5 & 8.04 & 11.89 & 7.67 & 10.72 & 8.86 & 14.57 & 8.19 & 12.29 \\
\hline 0.6 & 9.96 & 13.48 & 9.37 & 12.13 & 11.60 & 18.62 & 10.79 & 16.21 \\
\hline 0.7 & 12.04 & 15.74 & 11.41 & 13.77 & 16.47 & 26.82 & 15.43 & 22.61 \\
\hline 0.8 & 15.54 & 18.08 & 14.18 & 16.27 & 25.10 & 33.23 & 23.57 & 31.97 \\
\hline 0.9 & 20.68 & 21.42 & 19.82 & 20.02 & 45.67 & 56.13 & 45.45 & 55.47 \\
\hline
\end{tabular}

* Lower EMC values in salt-covered wood than in new wood 


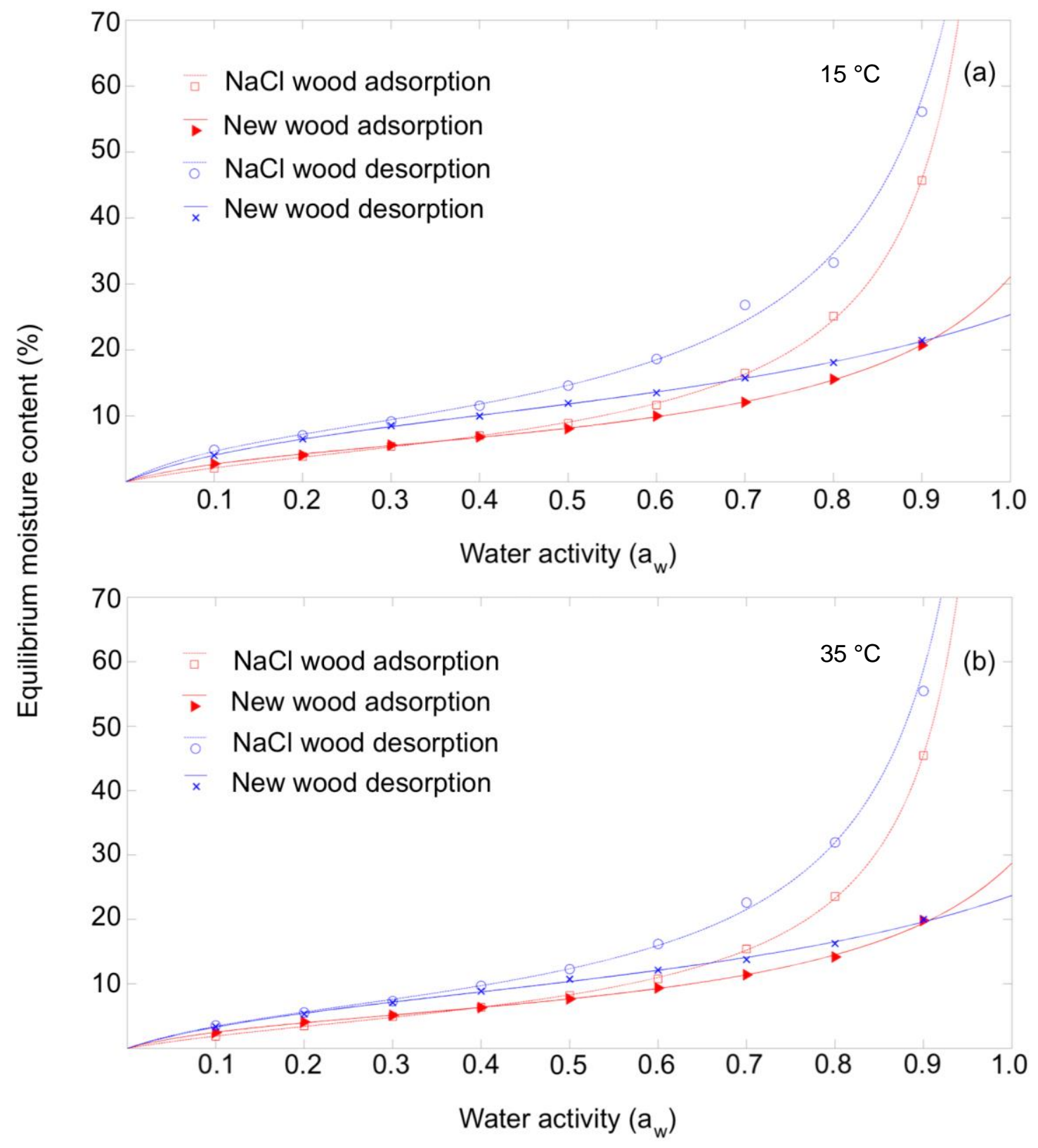

Fig. 3. $15^{\circ} \mathrm{C}$ and $35^{\circ} \mathrm{C}$ sorption isotherms of new wood and salt-covered wood ( $\mathrm{NaCl}$ wood)

This effect could be explained by the lower availability of - $\mathrm{OH}$ sites as a result of the mechanical barrier produced by the salt in the cell wall. Lesar et al. (2009) assumed that crystalline products such as sodium chloride are bound in wood mechanically rather than chemically and therefore the substances are deposited as smaller or larger crystals in cell walls and cell lumen. This barrier is more effective at lower air RH because at low $\mathrm{RH}$ the salt is crystallised in the cell wall. Salt penetration into the cell wall was also noted by Petr and Dejmal (2014), who reported up to $17 \%$ density increases for salt concentrations of $16 \mathrm{~g} / 100 \mathrm{~mL} \mathrm{H}_{2} \mathrm{O}$. In contrast, in desorption the moisture content in all the isotherms was higher in the salt-covered wood than in the new wood, probably as a consequence of the hysteresis process. 


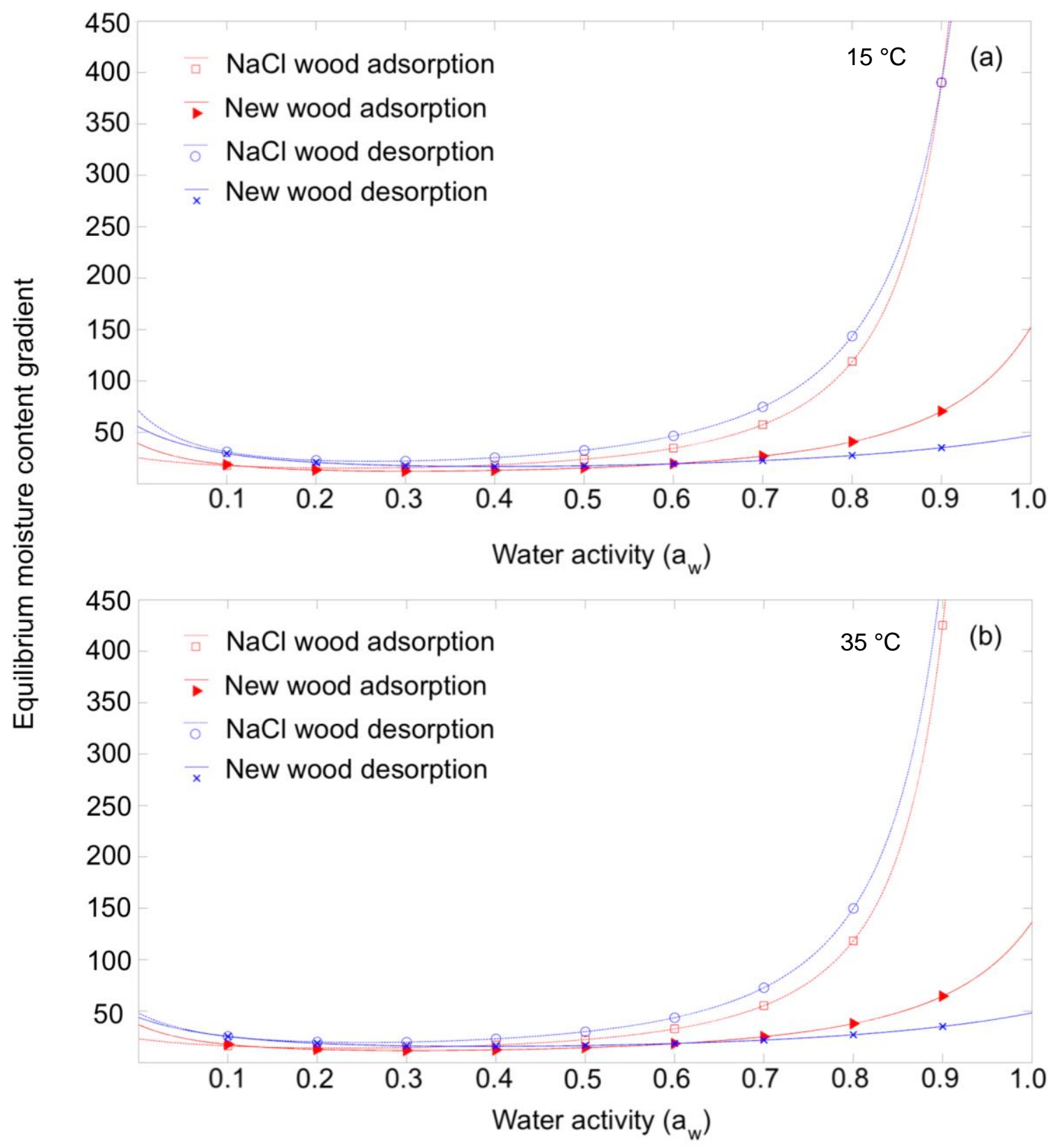

Fig. 4. Derivatives of the $15^{\circ} \mathrm{C}$ and $35^{\circ} \mathrm{C}$ sorption isotherms of new wood and salt-covered wood $(\mathrm{NaCl}$ wood)

The values of the minimum of the derivative of the EMC in relation to water activity corresponded to the points where multilayer sorption starts to predominate over monolayer sorption (Fig. 4 a, b). The monolayer saturation moisture content $\left(X_{\mathrm{m}}\right)$ showed no significant differences between the two types of wood (Table 2), although the RH values from which the multilayer predominates over the monolayer were significantly lower in the salt-covered wood. This result indicates the lower availability of - $\mathrm{OH}$ groups in the water sorption process in the salt-covered wood, which is more important in desorption than in adsorption due to the mechanical barrier of the salt in the cell wall. In studies on other species that had been buried, submerged, or buried under volcanic ash (Esteban et al. 2006, 2008a,b, 2009, 2010; Simon et al. 2017a), the RH values from which the multilayer predominates over the monolayer remained at around 30 to $40 \%$, 
despite the chemical changes in the cell wall. The new wood was in this RH range, but the salt in contact with the wood substantially modified this point of inflexion, and the monolayer became saturated at lower RH values. The salt in the wood also caused much steeper gradients, making the salt-covered wood more hygroscopically unstable (Fig. 4).

Table 2. GAB fit of New Wood and Salt-covered Wood (NaCl Wood)

\begin{tabular}{|c|c|c|c|c|c|}
\hline & \multicolumn{2}{|c|}{$15^{\circ} \mathrm{C}$ Isotherm } & \multicolumn{2}{|c|}{$35^{\circ} \mathrm{C}$ Isotherm } \\
\hline & & New wood & $\mathrm{NaCl}$ wood & New wood & $\mathrm{NaCl}$ wood \\
\hline \multirow{8}{*}{$\begin{array}{l}\text { 듬 } \\
\frac{0}{0} \\
\frac{0}{0} \\
\frac{0}{0}\end{array}$} & $X_{m}$ & $5.55 \pm 0.09$ & $5.66 \pm 0.08$ & $5.29 \pm 0.08$ & $5.15 \pm 0.07$ \\
\hline & $\mathrm{K}$ & $0.83 \pm 0.13$ & $0.978 \pm 0.09$ & $0.82 \pm 0.12$ & $0.99 \pm 0.08$ \\
\hline & $\mathrm{C}_{\mathrm{g}}$ & $8.69 \pm 0.02$ & $4.68 \pm 0.03$ & $8.55 \pm 0.02$ & $4.55 \pm 0.03$ \\
\hline & $\mathrm{R}$ & 0.999 & 0.999 & 0.999 & 0.999 \\
\hline & RMSE(\%) & 0.17 & 0.13 & 0.05 & 0.13 \\
\hline & (a) $\mathrm{RH}(\%)$ & 30.3 & 23.2 & 30.5 & 22.9 \\
\hline & (a) $\mathrm{EMC}_{\mathrm{a}}(\%)$ & 5.50 & 4.21 & 5.22 & 3.80 \\
\hline & (a) EMC $_{\mathrm{f}}(\%)$ & 0.05 & 1.45 & 0.07 & 1.35 \\
\hline \multirow{8}{*}{$\begin{array}{l}\text { 흐 } \\
\text { 흠 } \\
\text { ㅇ } \\
\Phi\end{array}$} & $\mathrm{X}_{\mathrm{m}}$ & $10.07 \pm 0.05$ & $8.65 \pm 0.13$ & $8.93 \pm 0.10$ & $7.31 \pm 0.09$ \\
\hline & $\mathrm{K}$ & $0.63 \pm 0.05$ & $0.95 \pm 0.18$ & $0.65 \pm 0.10$ & $0.98 \pm 0.12$ \\
\hline & $\mathrm{C}_{\mathrm{g}}$ & $8.90 \pm 0.01$ & $8.84 \pm 0.02$ & $7.59 \pm 0.02$ & $6.78 \pm 0.02$ \\
\hline & $\mathrm{R}$ & 0.999 & 0.997 & 0.999 & 0.997 \\
\hline & RMSE(\%) & 0.01 & 0.28 & 0.13 & 0.30 \\
\hline & (a) $\mathrm{RH}(\%)$ & 39.9 & 26.4 & 38.4 & 25.3 \\
\hline & (a) $\mathrm{EMC}_{\mathrm{d}}(\%)$ & 10.05 & 8.62 & 8.51 & 6.69 \\
\hline & (a) $\mathrm{EMC}_{\mathrm{f}}(\%)$ & 0.02 & 0.03 & 0.42 & 0.62 \\
\hline
\end{tabular}

$\mathrm{X}_{\mathrm{m}}$ : Monolayer saturation moisture content (\%); K: Constant; Cg: Guggenheim constant; R: Correlation coefficient; RMSE: Root Medium Square Error; RH: Relative humidity; $E \mathrm{MC}_{\mathrm{a}}$ : Equilibrium moisture content in adsorption; EMCd: Equilibrium moisture content in desorption; EMCf: Water taken up via monolayer sorption after the point of inflexion. (a) Point of inflexion of the isotherm.

The fibre saturation point (FSP) values were extraordinarily high in the saltcovered wood in both adsorption and desorption because of the hygroscopic nature of salt, particularly from the saturation point of the salt for water activities of 0.75 (Table 7).

The chemical composition of the new wood and the salt-covered wood showed significant differences (Table 3 ). Higher ash content was found for the salt-covered wood $(8.4 \%)$ than the new wood $(0.2 \%)$, indicating a higher amount of inorganic material (mainly salts). Both the cellulose and hemicellulose content were higher in the new wood than in the salt-covered wood. This result was expected, as sugar content decreases considerably in old wood (Iiyama et al. 1988). This effect may be due to attack by fungi and bacteria that degrade hemicellulose first (Blanchette 2000; Singh 2012).

The lignin content in the new wood was higher than in the salt-covered wood because, with the passage of time, lignin not only changes chemically with an increasingly different structure from its original state (Fengel 1991), but the action of certain microorganisms can also produce a process of delignification (Ferraz et al. 2008; Mendonça et al. 2008).

As in other studies (Simon et al. 2017a), the most significant changes occurred in the extractives content and were greater in the salt-covered wood $(10.2 \%)$ than in the new wood (4.1\%); this is because ageing typically results in higher extractives content in wood (Fengel 1991). 
Table 3. Chemical Composition of New Wood and Salt-Covered Wood ( $\mathrm{NaCl}$ Wood)

\begin{tabular}{|c|c|c|c|c|}
\hline & \multicolumn{2}{|c|}{ New wood } & \multicolumn{2}{|c|}{$\mathrm{NaCl}$ wood } \\
\hline & $\bar{x}$ & $\sigma$ & $\bar{x}$ & $\sigma$ \\
\hline Glucan (\%) & $43.57^{a}$ & 0.42 & $39.93^{b}$ & 0.01 \\
\hline Xylan (\%) & $9.98^{a}$ & 0.04 & $7.99^{b}$ & 0.17 \\
\hline Galactan (\%) & $0.00^{a}$ & 0.00 & $0.00^{a}$ & 0.00 \\
\hline Arabinan (\%) & $1.68^{a}$ & 0.01 & $1.31^{b}$ & 0.05 \\
\hline Mannan (\%) & $11.43^{a}$ & 0.13 & $10.88^{b}$ & 0.12 \\
\hline Total sugar (\%) & $66.66^{a}$ & 0.58 & $60.10^{b}$ & 0.1 \\
\hline Cellulose (\%) & $39.76^{a}$ & 0.38 & $36.30^{b}$ & 0.05 \\
\hline Hemicellulose (\%) & $26.9^{a}$ & 0.20 & $23.80^{\mathrm{b}}$ & 0.06 \\
\hline Hexosan (\%) & $15.24^{a}$ & 0.17 & $14.50^{b}$ & 0.16 \\
\hline Pentosan (\%) & $11.67^{a}$ & 0.03 & $9.30^{\mathrm{b}}$ & 0.22 \\
\hline Lignin (\%) & $25.6^{\mathrm{a}}$ & 0.16 & $22.3^{\mathrm{b}}$ & 0.19 \\
\hline Extractives (\%) & $4.1^{\mathrm{a}}$ & 0.00 & $10.2^{b}$ & 0.00 \\
\hline Ash content (\%) & $0.2^{\mathrm{a}}$ & 0.00 & $8.4^{\mathrm{b}}$ & 0.00 \\
\hline
\end{tabular}

Note: Different letters indicate significant differences $(p$-value $<0.05)$
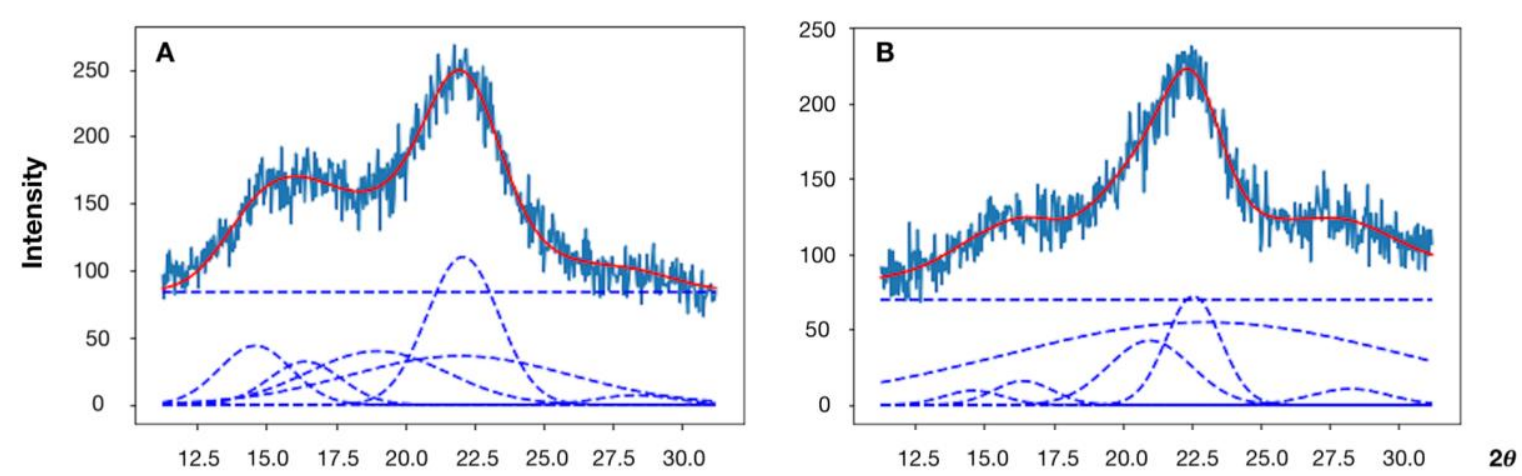

Fig. 5. X-ray diffraction patterns of a) new wood and b) salt-covered wood ( $\mathrm{NaCl}$ wood). Fits to the data of the different crystalline and the assumed amorphous Gaussian peaks

Figure 5 shows the X-ray patterns from the salt-covered wood samples and the new wood.

The crystallinity indices $(\mathrm{CrI} \%)$ showed significant differences between the two types of wood (Table 4) and were lower in the old wood, agreeing with similar studies on archaeological wood (Esteban et al. 2008b, 2009; Guo et al. 2018). This result could indicate a higher proportion of active centres and higher EMC in old wood. However, this was not the case. 
Table 4. Crystallinity Indices Crl\% and Average Dimension $\left(D_{200}\right)$ of the Cellulose Crystallite of New Wood And Salt-Covered Wood (NaCl wood)

\begin{tabular}{|l|l|l|l|l|}
\cline { 2 - 5 } \multicolumn{1}{c|}{} & \multicolumn{2}{l|}{ Crl\% } & \multicolumn{2}{l|}{$\mathrm{D}_{200}$} \\
\cline { 2 - 5 } \multicolumn{1}{c|}{} & $\bar{x}$ & $\sigma$ & $\bar{x}$ & $\sigma$ \\
\hline New wood & $49.67^{\mathrm{a}}$ & 5.13 & $26.85^{\mathrm{a}}$ & 0.62 \\
\hline NaCl wood & $20.33^{\mathrm{b}}$ & 1.53 & $33.90^{\mathrm{b}}$ & 1.92 \\
\hline
\end{tabular}

Note: Different letters indicate significant differences ( $p$-value $<0.05$ )

With $\mathrm{RH}$ around $30 \%$, where the multilayer starts to prevail over the monolayer, the old salt-covered wood exhibited lower EMC, probably because of mechanical blocking by the salt on one part of the active sites in the first isotherm interval; i.e., despite the higher number of active centres in the old wood, the salt prevented the water from accessing the active $-\mathrm{OH}$ sites.

Crystallite size $\left(\mathrm{D}_{200}\right)$ is greater in the wood in contact with salt than in the new wood. Guo et al. (2018) attributed this greater size in old wood to the degradation of the amorphous components of the surrounding cell wall and consequent reorganisation of the cellulose molecules.

Table 5. Estimated Concentration of -OH Groups in New Wood and SaltCovered Wood ( $\mathrm{NaCl}$ wood)

\begin{tabular}{|c|c|c|c|c|}
\cline { 2 - 5 } \multicolumn{1}{c|}{} & $\begin{array}{c}\text { Number of theoretical } \\
- \text {-OH groups }\left(\mathrm{mmol} \mathrm{g}{ }^{-1}\right)\end{array}$ & $\sigma$ & $\begin{array}{c}\text { Estimated number of accessible } \\
- \text { OH groups (Crystallinity index of } \\
\text { cellulose considered) }\left(\mathrm{mmol} \mathrm{g}^{-1}\right)\end{array}$ & $\sigma$ \\
\hline New wood & $13.37^{\mathrm{a}}$ & 0.1 & $9.72^{\mathrm{b}}$ & 0.06 \\
\hline $\mathrm{NaCl}$ wood & $12.06^{\mathrm{c}}$ & 0.02 & $10.69^{\mathrm{d}}$ & 0.02 \\
\hline
\end{tabular}

Note: Different letters indicate significant differences ( $p$-value $<0.05)$

The number of theoretical -OH groups and the estimated number of accessible $\mathrm{OH}$ groups in the two types of wood also showed significant differences (Table 5). The salt-covered wood had a lower crystallinity index and therefore a higher content of accessible $-\mathrm{OH}$ groups than the new wood. This result could explain the hygroscopic behaviour of each type of wood, particularly for the isotherm interval in which the monolayer prevails over the multilayer. However, such low points of inflexion where the multilayer prevails over the monolayer in the salt-covered wood $(23.3,26.4,22.9$, and 25.3) (Table 2) compared to the results of other studies on old, buried or submerged wood (Esteban et al. 2006, 2008a, b, 2009, 2010; Fernandez et al. 2014) indicate that the low EMC in adsorption in the salt-covered wood to $30 \% \mathrm{RH}$ may have been due to the mechanical barrier created by the salt.

FTIR spectra show that the two types of wood had the same characteristic peaks (Table 6, Fig. 6). However, the low relative intensity of the $\mathrm{C}=\mathrm{O}$ group (1730 to 1750 peak) in the salt-covered wood means that the relative glucuronic acid content of the xylan is lower than in the new wood (Navi and Sandberg 2011). 
Table 6. Main Functional Groups Present in Wood and Their Absorption Bands (Barker and Owen 1999; Chang and Chang 2002; Michell and Higgins 2002)

\begin{tabular}{|l|l|l|l|l|l|}
\hline \multirow{2}{*}{ Functional group } & Wave number & \multicolumn{2}{|l|}{ New wood } & \multicolumn{2}{l|}{ NaCl wood } \\
\cline { 3 - 6 } & $\left(\mathrm{cm}^{-1}\right)$ & $x$ & $\sigma$ & $x$ & $\sigma$ \\
\hline Hydroxyl $(-\mathrm{OH})$ & $3400-3500$ & 3345.9 & 0.76 & 3319.9 & 0.48 \\
\hline $\mathrm{C}-\mathrm{H}$ bond & $2890-2930$ & 2923.3 & 0.90 & 2922.1 & 1.04 \\
\hline Carbonyl $(\mathrm{C}=\mathrm{O})^{\mathrm{a}}$ & $1730-1750$ & 1731.5 & 0.62 & 1722.6 & 0.76 \\
\hline Lignin b $^{\mathrm{b}}$ & 1510 & 1508.3 & 0.34 & 1509.2 & 0.34 \\
\hline Deformation strains $\mathrm{CH}_{3}, \mathrm{CH}_{2}{ }^{\mathrm{c}}$ & 1370 & 1370.4 & 0.62 & 1371.8 & 0.62 \\
\hline Carboxyl $(\mathrm{C}-\mathrm{O})$ & 1200 & 1263.9 & 0.62 & 1264.3 & 0.90 \\
\hline
\end{tabular}

a Vibration of the acetyl and carboxyl groups of the xylan ring.

b Vibrations of the benzene ring in the lignin.

${ }^{c}$ Deformation in both the cellulose and the hemicellulose.

$\mathrm{NaCl}$ wood: salt-covered wood.

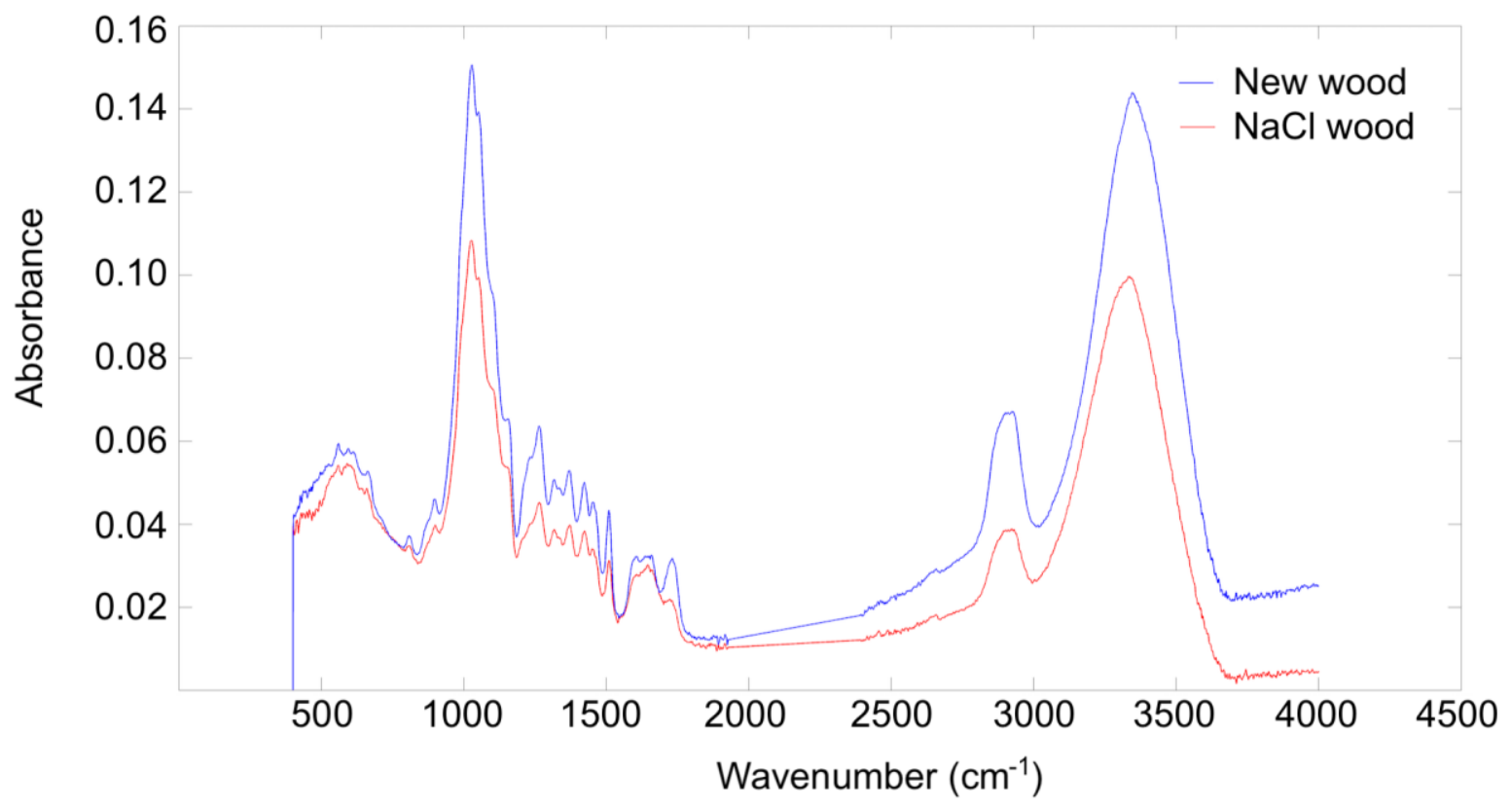

Fig. 6. FTIR spectra of new wood and salt-covered wood ( $\mathrm{NaCl}$ wood)

In addition, the low hydroxyl group content in the characteristic peak around 3350 $\mathrm{cm}^{-1}$ for the salt-covered wood was associated with the loss of cellulose and hemicellulose, as hemicellulose is the first component to degrade.

Table 7. Thermodynamic Parameters of New Wood and Salt-Covered Wood ( $\mathrm{NaCl}$ wood)

\begin{tabular}{|c|c|c|c|c|c|c|c|c|}
\hline & \multicolumn{4}{|c|}{ Adsorption } & \multicolumn{4}{|c|}{ Desorption } \\
\hline & \multirow{2}{*}{ FSP(\%) } & \multicolumn{2}{|c|}{$q_{\mathrm{s}}(\mathrm{KJ} / \mathrm{mol})$} & \multirow[t]{2}{*}{$\begin{array}{l}\mathrm{W}_{0}(\mathrm{KJ} / \mathrm{mol} \\
\text { dry wood) }\end{array}$} & \multirow{2}{*}{$\mathrm{FSP}(\%)$} & \multicolumn{2}{|c|}{$q_{\mathrm{s}}(\mathrm{KJ} / \mathrm{mol})$} & \multirow[t]{2}{*}{$\begin{array}{l}\mathrm{W}_{0}(\mathrm{KJ} / \mathrm{mol} \\
\text { dry wood) }\end{array}$} \\
\hline & & $\operatorname{Max}$ & $\min$ & & & Max & $\min$ & \\
\hline New wood & 31.10 & 3.38 & 0.58 & 0.47 & 25.35 & 9.65 & 1.15 & 1.38 \\
\hline $\mathrm{NaCl}$ wood & 459.82 & 4.14 & 0.11 & 0.52 & 298.23 & 15.42 & 0.49 & 2.08 \\
\hline
\end{tabular}


Analysis of the thermodynamic parameters (Table 7) showed that net isosteric heat of sorption was greater in desorption than in adsorption for both types of wood (Fig. 7). This occurred because the desorption process requires greater energy than the adsorption process (Siau 1995; Avramidis 1997). Similar results were obtained in other studies on old wood of different species in various ageing situations (Esteban et al. 2008a,b, 2009, 2010; Fernandez et al. 2014; Simon et al. 2017a). As EMC increases, net isosteric heat decreases, and the decrease is more pronounced in desorption than in adsorption. This behaviour was observed in other studies of both softwoods and hardwoods (Weichert 1963; Avramidis and Dubois 1992; Peralta et al. 1997; Hill et al. 2010). It is a result of the strong interaction between active $-\mathrm{OH}$ sites and water molecules at low EMC values (Telis et al. 2000) due to the existence of a high number of polar groups on the surface of the material that is occupied by the water molecules forming the monolayer (McMinn and Magee 2003). Once the active sites have been occupied, the water molecules that bond to the less active sites give rise to lower heats of sorption ( $\mathrm{Li}$ et al. 2011). If, in addition, the salt considerably increases the EMC, particularly above $70 \%$, this means that the salt-covered wood has a greater energy balance in the sorption process.

As expected, total heat of wetting was higher in desorption than in adsorption in the two types of wood, as more energy is involved in the desorption process. In both adsorption and desorption, the heat involved was greater in the salt-covered wood than in the new wood, probably because of the high hygroscopicity of the salt.

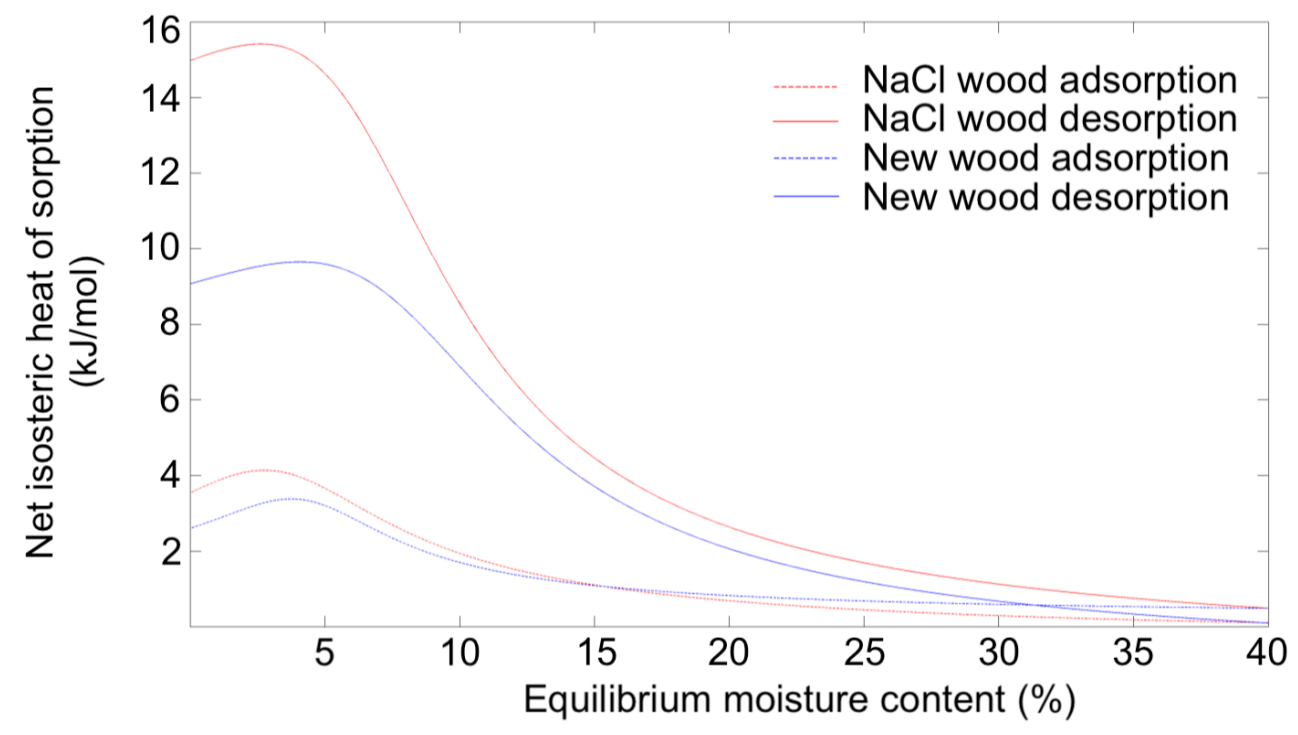

Fig. 7. Net isosteric heat of sorption of new wood and salt-covered wood ( $\mathrm{NaCl}$ wood)

It may be possible to gain a better understanding of the influence of salt on wood by impregnating recently felled wood to a range of salt concentrations and comparing their chemical composition, isotherms, and thermodynamic parameters.

\section{CONCLUSIONS}

1. The EMC values of the wood in prolonged contact with salt were higher than in the 
new wood for both isotherms, except for the first interval of the sorption isotherms, where mechanical blocking of the active sites may occur until multilayer sorption prevails over monolayer sorption.

2. The points from which multilayer sorption prevails over monolayer sorption were particularly low in the salt-covered wood.

3. The cellulose and hemicellulose contents were significantly lower in the salt-covered wood, although this wood had higher extractives content.

4. The number of active sorption sites was higher in the salt-covered wood.

5. The crystallinity index was lower in the salt-covered wood.

6. The energy involved in the desorption process was greater than in the adsorption process. Total heat of wetting was higher in the salt-covered wood.

\section{ACKNOWLEDGMENTS}

The authors are grateful to Consorci de Gerri de la Sal for assistance in this study, in particular Aroa Yagüe Medina, and to Angel Ruiz García, forest ranger, without whose assistance it would not have been possible to collect the samples. Professor Junji Sugiyama from University of Kyoto, Japan, is acknowledged for the XRD results.

\section{REFERENCES CITED}

Andersson, S., Serimaa, R., Paakkari, T., Saranpaa, P., and Pesonen, E. (2003). "Crystallinity of wood and the size of cellulose crystallites in Norway spruce (Picea abies)," J. Wood Sci. 49, 531-537. DOI: 10.1007/s10086-003-0518-X

Andersson, S., Wikberg, H., Pesonen, E., Maunu, S. L., and Serimaa, R. (2004). "Studies of crystallinity of Scots pine and Norway spruce cellulose," Trees-Struct Funct 18, 346-353. DOI: 10.1007/s00468-003-0312-9

Arevalo-Pinedo, A., Giraldo-Zuñiga, A. D., Dos Santos, F. L., and Arevalo, R. P. (2004). "Sorption isotherms experimental data and mathematical models for murici pulp (Byrsonima sericea)," in: Proceedings of the 14th International Drying Symposium, Sao Paulo, Brazil.

Avramidis, S., and Dubois, J. (1992). "Sorption energies of some Canadian species," Holzforschung 46, 177-179.

Avramidis, S. (1997). "The basics of sorption," in: Proceedings of International Conference of COST Action E8: Mechanical Performance of Wood and Wood Products, Copenhagen, Denmark.

Barker, B., and Owen, N. L. (1999). "Identifying softwoods and hardwoods by infrared spectroscopy," J. Chem. Educ. 76(12), 1706-1709. DOI: 10.1021/ed076p1706

Blanchette, R. A., Cease, K. R., Abad, A. R., Burnes, T. A., and Obst, J. R. (1991). "Ultrastructural characterization of wood from Tertiary fossil forests in the Canadian Arctic," Can. J. Bot. 69, 560-568. DOI: 10.1139/b91-076

Blanchette, R.A. (2000). "A review of microbial deterioration found in archaeological wood from different environments," Int. Biodeter. Biodegr. 46, 189-204. DOI: 10.1016/S0964-8305(00)00077-9 
Bonarski, J. T., and Olek, W. (2011). "Application of the crystalline volume fraction for characterizing the ultrastructural organization of wood," Cellulose 18, 223-235. DOI: 10.1007/s10570-010-9486-7

Chang, H. T., and Chang, S. T. (2002). "Moisture excluding efficiency and dimensional stability of wood improved by acylation," Bioresource Technol. 85, 201-204. DOI: 10.1016/S0960-8524(02)00085-8

Easty, D. B., and Malcolm, E. W. (1982). "Estimation of pulping yield in continuous digesters from carbohydrate and lignin determinations," Tappi J. 65, 78-80.

Elesini, U. S., Cuden, A. P., and Richards, A. F. (2002). "Study of the green cotton fibres," Acta Chim. Slov. 49, 815-833.

Engelund, E. T., Thygesen, L. G., Svensson, S., and Hill, C. (2013). "A critical discussion of the physics of wood-water interactions," Wood Sci. Technol. 47, 141161. DOI: $10.1007 / \mathrm{s} 00226-012-0514-7$

Esteban, L. G., and Guindeo, A. (1988). Anatomía e identificación de maderas de coníferas españolas Aitim, Madrid, Spain.

Esteban, L. G., de Palacios, P., Guindeo, A., García, L., Lázaro, I., González, L., Rodríguez, Y., García, F., Bobadilla, I., and Camacho, A. (2002). Anatomía e Identificación de Maderas de Coníferas a Nivel de Especie/Anatomy and Identification of Coniferous Wood as a Species, Fundación Conde del Valle de Salazar-Mundi-Prensa, Madrid, Spain.

Esteban, L. G., Fernandez, F. G., Guindeo, A., de Palacios, and P., Gril, J. (2006). "Comparison of the hygroscopic behaviour of 205-year-old and recently cut juvenile wood from Pinus sylvestris L.," Ann. For. Sci. 63, 309-317. DOI: 10.1051/forest:2006010

Esteban, L. G., de Palacios, P., Fernandez, F. G., Guindeo, A., and Cano, N. N. (2008a). "Sorption and thermodynamic properties of old and new Pinus sylvestris wood," Wood Fiber Sci. 40, 111-121.

Esteban, L. G., de Palacios, P., Fernandez, F. G., Guindeo, A., Conde, M., and Baonza, V. (2008b). "Sorption and thermodynamic properties of juvenile Pinus sylvestris L. wood after 103 years of submersion," Holzforschung 62, 745-751. DOI: 10.1515/HF.2008.106

Esteban, L. G., de Palacios, P., García Fernandez, F., Martin, J. A., Genova, M., and Fernandez-Golfin, J. I. (2009). "Sorption and thermodynamic properties of buried juvenile Pinus sylvestris L. wood aged 1,170 \pm 40 BP.," Wood Sci. Technol. 43, 140151. DOI: 10.1007/s00226-009-0261-6

Esteban, L. G., de Palacios, P., Fernandez, F. G., and Garcia-Amorena, I. (2010). "Effects of burial of Quercus spp. wood aged $5910 \pm 250 \mathrm{BP}$ on sorption and thermodynamic properties," Int. Biodeter. Biodegr. 64, 371-377. DOI: 10.1016/j.ibiod.2010.01.010

Fengel, D. (1991). "Aging and fossilization of wood and its components," Wood Sci. Technol. 25, 153-177. DOI: 10.1007/BF00223468

Fernandez, F. G., Esteban, L. G., de Palacios, P., Simon, C., Garcia-Iruela, A., and de la Fuente, J. (2014). "Sorption and thermodynamic properties of Terminalia superba Engl. \& Diels. and Triplochiton scleroxylon K. Schum. through the 15,35 and $50{ }^{\circ} \mathrm{C}$ sorption isotherms," Eur. J. Wood Wood Prod. 72, 99-106. DOI: 10.1007/s00107013-0752-X

Ferraz, A., Guerrab, A., Mendonça, R., Masarina Marcos, F., Vicentim, P., Aguiar, A., and Pavand, P. C. (2008). "Technological advances and mechanistic basis for fungal biopulping," Enzyme Microb. Tech. 43(2), 178-185. DOI: 
10.1016/j.enzmictec.2007.10.002

Fredriksson, M., and Thybring, E. E. (2018). "Scanning or desorption isotherms?. Characterising sorption hysteresis of wood," Cellulose 25(8), 4477-4485. DOI: 10.1007/s10570-018-1898-9

French, A. D., and Santiago Cintrón, M. (2013). "Cellulose polymorphy, crystallite size, and the Segal crystallinity index," Cellulose 20, 583-588. DOI: 10.1007/s10570-0129833-y

French, A.D. (2014). "Idealized powder diffraction patterns for cellulose polymorphs," Cellulose 21, 885-896. DOI: 10.10007/s10570-013-0030-4

Garcia Fernandez, F. (2004). Histéresis Higroscópica de la Madera Antigua de Pinus sylvestris L., Master's Thesis, Universidad Politécnica de Madrid, Madrid, Spain.

Garvey, C. J., Parker, I. H., and Simon, G. P. (2005). "On the interpretation of X-ray diffraction powder patterns in terms of the nanostructure of cellulose I fibres," Macromol. Chem. Phys. 206 (15), 1568-1575.

Guo, J., Rennhofer, H., Yin, Y., and Lichtenegger, H. (2016). "The influence of thermohygro-mechanical treatment on the micro- and nanoscale architecture of wood cell walls using small- and wide-angle X-ray scattering," Cellulose 23, 2325-2340. DOI: 10.1007/s10570-016-0982-2

Guo, J., Zhou, H., Stevanic, J. S., Dong, M., Yu, M., Salmén, L., and Yin, Y. (2018). "Effects of ageing on the cell wall and its hygroscopicity of wood in ancient timber construction," Wood Sci. Technol. 52, 131-147. DOI: 10.1007/s00226-017-0956-Z

Hill, C., and Jones, D. (1996). "The dimensional stabilisation of Corsican pine sapwood by reaction with carboxylic acid anhydrides. The effect of chain length," Holzforschung 50, 457-462. DOI: 10.1515/hfsg.1996.50.5.457

Hill, C., and Jones, D. (1999). "Dimensional changes in Corsican pine sapwood due to chemical modification with linear chain anhydrides," Holzforschung 53, 267-271. DOI: $10.1515 /$ HF.1999.045

Hill, C. (2006). Wood Modification. Chemical, Thermal and Other Processes, John Wiley \& Sons, Ltd, Hoboken, USA. DOI: 10.1002/0470021748.

Hill, C., Norton, A., and Newman, G. (2009). "The water vapor sorption behavior of natural fibers," J. Appl. Polym. Sci. 112, 1524-1537. DOI: 10.1002/app.29725

Hill, C., Norton, A. J., and Newman, G. (2010). "The water vapour sorption properties of Sitka spruce determined using a dynamic vapour sorption apparatus," Wood Sci. Technol. 44, 497-514. DOI: 10.1007/s00226-010-0305-y

Hult, L. E., Iversen, T., and Sugiyama, J. (2003). "Characterization of the supramolecular structure of cellulose in wood pulp fibres," Cellulose 10, 103-110. DOI: 10.1023/A:1024080700873

IAWA Committee (2004). "IAWA list of microscopic features for softwood identification," IAWA J. 25, 1-70.

Iiyama, K., Kasuya, N., Lam, T. B. T., Nakano, J., and Sakaguchi, H. (1988). "Chemical characterization of ancient buried wood," Holzforschung 42, 5-10. DOI: 10.1515/hfsg.1988.42.1.5

Jahan, M. S, and Mun, S. P. (2005). "Effect of tree age on the cellulose structure of Nalita wood (Trema orientalis)," Wood Sci. Technol. 39, 367-373. DOI:10.1007/s00226005-0291-7

Jannot, Y., Kanmogne, A., Talla, A., and Monkam, L. (2006). "Experimental determination and modelling of water desorption isotherms of tropical woods: Afzelia, Ebony, Iroko, Moabi and Obeche," Holz Roh Werkst 64, 121-124. DOI: 
10.1007/s00107-005-0051-2

Jones, P. D., Schimleck, L. R., Peter, G. F., Daniels, R. F., and Clark, A. (2006).

"Nondestructive estimation of wood chemical composition of sections of radial wood strips by diffuse reflectance near infrared spectroscopy," Wood Sci. Technol. 40, 709720. DOI: 10.1007/s00226-006-0085-6

Kollmann, F. (1959). Tecnología de la Madera y sus Aplicaciones. Tomo primero, Traducida de la segunda edición alemana por el Instituto Forestal de Investigaciones y Experiencia y el Servicio de la Madera, Ministerio de Agricultura, Dirección General de Montes, Caza y Pesca Fluvial, Instituto Forestal de Investigaciones y Experiencia y el Servicio de la Madera, Madrid, Spain.

Leppänen, K., Andersson, S., Torkkeli, M., Knaapila, M., Kotelnikova, N., and Serimaa, R. (2009). "Structure of cellulose and microcrystalline cellulose from various wood species, cotton and flax studied by X-ray scattering," Cellulose 16, 999-1015. DOI: 10.1007/s10570-009-9298-9

Lesar, B., Gorisek, Z., and Humar, M. (2009). "Sorption properties of wood impregnated with boron compounds, sodium chloride and glucose," Dry Technol. 2, 94-102. DOI: 10.1080/07373930802565947

Li, X. J., Cao, Z. Y., Wei, Z.Y., Feng, Q.Y., and Wang, J. S. (2011). "Equilibrium moisture content and sorption isosteric heats of five wheat varieties in China," $J$. Stored Prod. Res. 47, 39-47. DOI: 10.1016/j.jspr.2010.10.001

Lionetto, F., Del Sole, R., Cannoletta, D., Vasapollo, G., and Maffezzoli, A. (2012). "Monitoring wood degradation during weathering by cellulose crystallinity," Materials 5, 1910-1922. DOI: 10.3390/ma5101910

Martín, J. A., Esteban, L. G., de Palacios, P., and García Fernández, F. (2010). "Variation in wood anatomical traits of Pinus sylvestris L. between Spanish regions of provenance," Trees 24, 1017-1028. DOI: 10.1007/s00468-010-0471-4

McMinn, W. A. M., and Magee, T. R. A. (2003). "Thermodynamic properties of moisture sorption of potato," J. Food. Eng. 60, 157-165. DOI: 10.1016/S02608774(03)00036-0

Mendonça, R. T., Jara, J. F., González, V., Elissetche, J. P., and Freer, J. (2008). "Evaluation of the white-rot fungi Ganoderma australe and Ceriporiopsis subvermispora in biotechnological applications," J. Ind. Microbiol. Biotechnol. 35(11), 1323-30. DOI: 10.1007/s10295-008-0414-X

Michell, A. J., and Higgins, H. G. (2002). Wood Chemistry, Infrared Spectroscopy in Australian Forest Products Research, CSIRO Forestry and Forest Products, Victoria, Australia.

Navi, P., and Sandberg, D. (2011). Thermo-Hydro-Mechanical Processing of Wood, EPFL Press, Lausanne, Switzerland.

Park, S., Johnson, D. K., Ishizawa, C. I., Parilla, P. A., and Davis, M. F. (2009). "Measuring the crystallinity index of cellulose by solid state $13 \mathrm{C}$ nuclear magnetic resonance," Cellulose 16(4), 641-647. DOI:10.1007/s10570-009-9321-1

Park, S., Baker, J. O., Himmel, M. E., Parilla, P. A., and Johnson, D. K. (2010). "Cellulose crystallinity index: Measurement techniques and their impact on interpreting cellulase performance," Biotechnol. Biofuels 3, 10. DOI: 10.1186/17546834-3-10

Peralta, P. N., Bangi, A. P., and Lee, A. W. C. (1997). "Thermodynamics of moisture sorption by the giant-timber bamboo," Holzforschung 51, 177-18. DOI:

10.1515/hfsg.1997.51.2.177 
Petr, P., and Dejmal, A. (2014). "Moisture absorption and dimensional stability of poplar wood impregnated with sucrose and sodium chloride," Maderas-Cienc. Tecnol. 16, 299-311.

Popescu, C. M., and Hill, C. (2013). "The water vapour adsorption-desorption behaviour of naturally aged Tilia cordata Mill.," Wood. Polym. Degrad. Stabil. 98, 1804-1813. DOI: 10.1016/j.polymdegradstab.2013.05.021

Rambo, M. K. D., and Ferreira M. M. C. (2015). "Determination of cellulose crystallinity of banana residues using near infrared spectroscopy and multivariate analysis," $J$. Braz. Chem. Soc. 26 (7), 1491-1499. DOI: 10.5935/0103-5053.20150118

Rautkari, L., Hill, C., Curling, S., Jalaludin, Z., and Ormondroyd, G. (2013). "What is the role of the accessibility of wood hydroxyl groups in controlling moisture content?," $J$. Mater. Sci. 48, 6352-6356. DOI: 10.1007/s10853-013-7434-2

Rowell, R. M. (1980). "Distribution of reacted chemicals in southern pine modified with methyl isocyanate," Wood Sci. 13, 102-110.

Segal, L., Creely, J. J., Martin, A. E., and Conrad, C. M. (1959). "An empirical method for estimating the degree of crystallinity of native cellulose using X-ray diffractometer," Text. Res. J. 29, 786-794.

Siau, J. F. (1995). Wood: Influence of Moisture on Physical Properties, Department of Wood Science and Forest Products, Virginia Polytechnic Institute and State University, Blacksburg, USA.

Simon, C., Esteban, L. G., de Palacios, P., Fernandez, F. G., García-Iruela, A., MartínSampedro, R., and Eugenio, M. E. (2017a). "Sorption and thermodynamic properties of wood of Pinus canariensis C. Sm. ex DC. buried in volcanic ash during eruption," Wood Sci. Technol. 51, 517-534. DOI: 10.1007/s00226-016-0884-3

Simon, C., Esteban, L. G., de Palacios, P., Fernandez, F. G., Hosseinpourpia, R., and Carsten Mai, C. (2017b). "Comparison of the saturated salt and dynamic vapor sorption methods in obtaining the sorption properties of Pinus pinea L.," Eur. J. Wood Wood Prod. 75, 919-926. DOI 10.1007/s00107-016-1155-6

Simpson. (1980). "Sorption theories applied to wood," Wood Fiber Sci. 12, 183-195.

Singh, A. P. (2012). "A review of microbial decay types found in wooden objects of cultural heritage recovered from buried and waterlogged environments," J. Cult. Herit. 13, 516-520. DOI: 10.1016/j.culher.2012.04.002

Sluiter, A., Ruiz, R., Scarlata, C., Sluiter, J., and Templeton, D. (2005). Determination of Extractives in Biomass, National Renewable Energy Laboratory, Golden, CO, USA.

Sluiter, A., Hames, B., Ruiz, R., Scarlata, C., Sluiter, J., Templeton, D., and Crocker, S. (2012). Determination of Structural Carbohydrates and Lignin in Biomass (NREL/TP-510-42618), National Renewable Energy Laboratory, Golden, CO, USA.

TAPPI T211 om-02 (2002). "Ash in wood, paper and paperboard: Combustion at 525 ${ }^{\circ} \mathrm{C}$, , TAPPI Press, Atlanta, GA.

Teeäär, R., Serimaa, R., and Paakkarl, T. (1987). "Crystallinity of cellulose, as determined by CP/MAS NMR and XRD methods," Polym. Bull. 17, 231-237. DOI: 10.1007/BF00285355

Telis, V. R. N., Gabas, A. L., Menegalli, F. C., and Telis-Romero, J. (2000). "Water sorption thermodynamic properties applied to persimmon skin and pulp," Thermochim. Acta 343, 49-56. DOI: 10.1016/S0040-6031(99)00379-2

Thygesen, A., Oddershede, J., Lilholt, H., Thomsen, A. B., and Stahl, K. (2005). "On the determination of crystallinity and cellulose content in plant fibres," Cellulose 12, 563576. DOI: $10.1007 / \mathrm{s} 10570-005-9001-8$ 
Vaaler, D., Syverud, K., Seem, B., and Moe, S. T. (2005). "Estimating the pulping yield by carbohydrate analysis," Tappi J. 4, 23-27.

Viollaz, P. E., and Rovedo, C. O. (1999). "Equilibrium sorption isotherms and thermodynamic properties of starch and gluten," J. Food Eng. 40 DOI: 10.1016/S0260-8774(99)00066-7

Wazny, J. (1993) "The present classification of wood degradation factors," Folia Forestalia Polonica Serie B 24, 13-22.

Weichert, L. (1963). "Investigations on sorption and swelling of spruce, beech and compressed beech wood between $20^{\circ}$ and $100^{\circ}$," Holz Roh Werkst 21, 290-300. DOI: 10.1007/BF02610962

Wilkins, A. P., and Simpson, J. A. (1988). "Difibring of roof timbers," J. I. Wood Sci. 11, 121-25.

Zahian, J., Hill, C., Hashim, W. S., Dahlan, J. M., and Sun, D. Y. (2011). "Analysis of the water vapour sorption isotherms of oil palm trunk and rubberwood," J. Trop. For. Sci. 23, 97-105.

Zelinka, S. L., Glass, S. V., and Thybring, E. E. (2018). "Myth versus reality: Do parabolic sorption isotherm models reflect actual wood-water thermodynamics?," Wood Sci. Technol. 52, 1701-1706. DOI: 10.1007/s00226-018-1035-9

Article submitted: November 29, 2018; Peer review completed: January 13, 2019; Revised version received: February 18, 2019; Accepted: February 19, 2019; Published: February $25,2019$.

DOI: 10.15376/biores.14.2.3069-3091 